\title{
Os Jovens do Cuca Jangurussu:
}

\section{a dança como forma de expressão cultural e inclusão social.}

\section{Sâmia Cristiane Moura da Conceição Holanda}

Mestre em Planejamento em Políticas Publicas - UECE

\section{Francisco Horácio da Silva Frota}

Doutor em Sociologia pela Universidade de Salamanca - Espanha

Professor do Programa de Pós-Graduação em Políticas Públicas (PPGPP) da UECE

\section{Resumo}

Este artigo apresenta um estudo das contribuições do Centro Urbano de Cultura, Arte, Ciência e Esporte - CUCA Jangurussu no processo de inclusão social dos jovens da periferia. Implantados estrategicamente em bairros de periferia, com elevada concentração de jovens, os CUCAs oferecem atividades de formação e capacitação nas áreas de cultura, arte, ciência e esporte, de forma integrada, descentralizada e democrática. A perspectiva desta pesquisa é demonstrar a participação dos jovens inseridos em um dos programas do CUCA, denominado Comunidade em Pauta, que visa à cessão de espaços aos participantes para desenvolverem habilidades artísticas, culturais e esportivas, sendo que, foram estudados os que praticam atividades artístico-culturais, em especial, na área da dança. Os estudos de campo no CUCA Jangurussu e as entrevistas possibilitaram conhecer as diversas atividades desenvolvidas no equipamento, as práticas sociais dos jovens nesse espaço e as experiências vivenciadas através da dança como forma de expressão cultural e inclusão social desses jovens.

Palavras-chave: Juventude. Políticas públicas de juventude. Culturas juvenis. Sociabilidade. Inclusão social. 


\section{Abstract}

This article presents a study of the contributions of the Urban Center of Culture, Art, Science and Sport - CUCA Jangurussu in the process of social inclusion of the youth of the periphery. Strategically deployed in suburban neighborhoods with a high concentration of young people, CUCAs offer training and capacity building activities in the areas of culture, art, science and sports, in an integrated, decentralized and democratic way. The perspective of this research is to demonstrate the participation of the young people included in one of the CUCA programs, called Comunidade em Pauta, which aims at assigning spaces to the participants to develop artistic, cultural and sporting skills, being studied those who practice artistic activities Particularly in the area of dance. The field studies at CUCA Jangurussu and the interviews allowed to know the various activities developed in the equipment, the social practices of the young people in this space and the experiences lived through the dance as a form of cultural expression and social inclusion of these young people.

Key words: Youth. Public policies for youth. Youth culture. Sociability. Social inclusion 


\section{Introdução}

Este artigo abordará os jovens inseridos em atividades artístico-culturais do programa Comunidade em Pauta do Centro Urbano de Cultura, Arte, Ciência e Esporte - CUCA Jangurussu.

Este programa é referenciado pela equipe de Participação Juvenil, que faz parte da Diretoria de Promoção de Direitos Humanos, e é voltado para a cessão de espaços físicos da Rede Cuca visando à formação, fomento e difusão da produção cultural, artística e esportiva de jovens e grupos juvenis autônomos, da faixa etária de 15 a 29 anos, que desejam desenvolver essas atividades e não disponham de ambientes adequados para tais práticas.

A disponibilização do espaço CUCA tem como propósito, sobretudo, de criar vínculos com os jovens, através da ação ativa e propositiva das programações promovidas no equipamento, dando visibilidade e incentivando-os à profissionalização e ao aperfeiçoamento de suas atividades.

Pensar em política pública para a juventude de Fortaleza tornou-se uma preocupação e um desafio tanto para os poderes públicos como para a sociedade civil, de modo a atender os anseios e as expectativas dessa categoria, assim como reduzir os problemas da criminalidade, consumo de álcool e drogas, tráfico, entre outros que tanto afetam esses jovens.

Nesse contexto, a Prefeitura Municipal de Fortaleza, com o propósito de instituir uma política que pudesse agregar o protagonismo, a criatividade e a inclusão social, criou os Centros Urbanos de Cultura, Arte, Ciência e Esporte voltados para jovens. Esses equipamentos foram demandados do Orçamento Participativo (OP) pelo segmento da juventude, sendo construídos estrategicamente em bairros com elevada concentração de população jovem de baixa renda e de alta vulnerabilidade de risco, atendendo à divisão das regiões administrativas da cidade, e, atualmente, três unidades estão em pleno funcionamento: da Barra do Ceara, do Mondubim e do Jangurussu, que fazem parte, respectivamente, das Secretarias Executivas Regionais I, V e VI, e juntos formam a Rede CUCA ..

Os CUCAs são considerados também locais de encontro e convivência da população jovem, ou seja, são espaços de sociabilidade, de participação juvenil, que possibilitam diversas formas de interação, de realização e de vivência dos valores e dos comportamentos.

Para Dayrell (2007, p. 1110) "o mundo da cultura aparece como um espaço privilegiado de práticas, representações, símbolos e rituais, no qual os jovens buscam demarcar uma identidade juvenil". Alerta o autor para a importância de situar o lugar social dos jovens, pois é o que vai determinar a condição juvenil, e a vivência da juventude nas camadas populares é dura e difícil. Ao lado da sua condição como jovens, alia-se a da pobreza, numa dupla condução que interfere diretamente na trajetória de vida e nas possibilidades e sentidos que assumem a vivência juvenil. 
Assim, importa entender de que maneira as práticas culturais desenvolvidas pelos jovens, no contexto das ações culturais do programa Comunidade em Pauta, no espaço CUCA contribuem para sua inclusão social e como esses jovens utilizam esse local como parte da dinâmica de sociabilidade juvenil, haja vista que é um lugar que proporciona oportunidades de tecer novas redes de sociabilidade, contribuindo para uma nova visão de mundo, sendo, ainda, fundamental na elaboração da sua identidade.

Com base nas entrevistas, realizadas no período de fevereiro a abril/2017, com dez jovens dos diversos coletivos do Programa Comunidade em Pauta, bem como outros jovens, que contribuíram através de conversas informais, além das entrevistas com funcionários do CUCA Jangurussu foram essenciais para a compreensão da dinâmica e funcionalidade do lugar, assim como, conhecer mais de perto os jovens que lá frequentam, suas opiniões sobre o trabalho desenvolvido no equipamento e se as atividades ofertadas estão atendendo suas demandas.

\section{Juventude (S): olhares atribuído pela sociedade}

A partir dos anos 90, a juventude, como categoria social, passa a ter mais expressão no cenário público e político, tendo, como uma das razões, o aumento expressivo de jovens no Brasil.

Há os que consideram o jovem como transgressor da ordem social, problemático e em situação de vulnerabilidade, reforçando a percepção generalizada da juventude, ou ainda como elemento fundamental nas políticas públicas de desenvolvimento concebidas como forma de solucionar os problemas sociais e econômicos. Segundo Catani e Gilioli (2008, p. 96):

[...] vários estudos 'regrediram' a perspectivas que enfocam o jovem como 'problema'. O estudo da delinquência voltou a assumir grande importância a partir da década de 1980, com os temas dos 'jovens urbanos', das 'gangues' e dos grupos com comportamentos supostamente 'desviantes' (punk, por exemplo). Na década de 1990 (e até hoje), também houve movimento a fim de enfocar a juventude como capital humano a ser aproveitado economicamente. Os jovens continuaram a ser encarados como 'problema social' - por exemplo, pelo viés da violência urbana -, com a diferença que a 'solução' não seria mais o simples emprego dos antigos métodos de repressão dos comportamentos e de rebeldia. Assim entravam na cena principal as políticas públicas como tentativa de integrar os jovens excluídos no mercado de trabalho. 
Com a entrada em vigor do Estatuto da Criança e do Adolescente (ECA), Lei no 8.069, em 1990, por muito tempo, o termo juventude era associado ao período da adolescência ou da faixa etária distinta da criança. Pelo histórico, observa-se que as ações, serviços e programas do Estado e das entidades da sociedade civil adotavam o limite máximo de 18 anos, o que excluía os maiores de 18 a 29 anos, isto é, os jovens dessas faixas etárias não eram abrangidos pelas ações e debates sobre direitos e cidadania contidos no ECA.

Na década de 90, as políticas públicas para juventude visavam setores que apresentavam características de vulnerabilidade, risco ou transgressão, geralmente os grupos visados eram a juventude urbana, pobre e negra, assim como as iniciativas eram bem pontuais, de curta duração e voltadas à inclusão social de jovens por meio de oficinas de capacitação para inserção no mundo do trabalho.

Para Diógenes (2009, p. 278), uma política para juventude deve levar em conta aspectos que recortam o conjunto de suas experiências, suas formas de sociabilidade e as marcas e os códigos de linguagem que balizam suas linhas de comunicação e produzem um reconhecimento entre seus pares. Ressalta a autora que muitas políticas públicas para juventude pautam-se em iniciativas restritas de profissionalização e geração de renda sob os parâmetros do mundo adulto.

Em fevereiro de 2005, através da Lei № 11.129/05, foram instituídos a Secretaria Nacional de Juventude (SNJ), órgão executivo ligado à Secretaria-Geral da Presidência da República; o Conselho Nacional de Juventude (CONJUVE), órgão de articulação entre o governo e a sociedade civil, consultivo e propositivo. A partir desses órgãos, possibilitou mais diálogos entre governo e juventude, e consequentemente houve maior direcionamento no processo de construção das políticas públicas para a juventude.

Em 05 de agosto de 2013 foi instituído o Estatuto da Juventude, através da Lei no 12.852, decorrente de lutas históricas dos movimentos juvenis organizados e representa o primeiro marco legal específico a reconhecer as pessoas com idade entre 15 a 29 anos como sujeitos de direitos, tendo entrado em vigor em primeiro de fevereiro de 2014.

\subsection{Juventude, culturas juvenis e sociabilidade}

Para compreender o que vem a ser a juventude, Catani e Giolioli (2008, p. 12-13) ressaltam que é necessário começar desmistificando-a como categoria natural e biológica, quando na verdade ela é, sobretudo, uma construção social que varia conforme as diferentes culturas, e que nem sempre existiu como categoria socialmente visível.

A importância de se definir o início e o término da idade do período da juventude é para diferenciá-la dos demais grupos da população. Ademais, torna-se necessária distingui-la, pois definirá, por exemplo, para quem serão destinados os recursos, projetos, ações e políticas públicas voltadas para os jovens. 
Todavia, definir a juventude não somente como um recorte de faixa etária, mas também como categoria social, implica compreender a existência de vários grupos sociais concretos que constituem uma pluralidade de juventudes, visto que de cada recorte sociocultural emergem subcategorias de indivíduos jovens com características, símbolos, comportamentos e sentimentos específicos. Nessa linha esclarece Carrano (2003, p. 133-134)

\begin{abstract}
A juventude se mantem como categoria sociológica inventada pelos adultos, entretanto os seus sentidos se tornam cada vez mais difíceis de totalizar. Quando muito, podemos elaborar provisórios mapas relacionais. [...] O cotidiano dos jovens pode ser mais caracterizado, entretanto, por inúmeras redes de interesses cotidianos com os grupos e redes de reações elaborando seus próprios estilos e pontos de vistas.
\end{abstract}

Assim, o conceito de "juventudes plurais" seria o mais adequado, tendo em vista às diferenças de ser jovem em função das classes sociais, de habitar no centro de grande metrópole ou em periferia, de pertencer a religiões e credos distintos, de orientação sexual, sua condição étnica e de gênero, entre outros fatores, que vão diferenciando internamente o grupo que se denomina juventude, razão pela qual, ao falar das experiências juvenis, deve-se reconhecer esta diversidade e pronunciar "juventudes", noção esta compartilhada por diversos autores (SPOSITO; CARRANO, 2003; DAYRELL, 2007; PAIS, 1990, entre outros).

A força da indústria cultural colabora sobremaneira para diversas formas de exclusões e diferenciações entre as múltiplas condições juvenis, conforme advertem Catani e Gilioli (2008, p. 20) ao citar os casos dos jovens pobres que têm possibilidades reduzidas, ou até mesmo, inexistentes de consumir em espaços como restaurantes, concertos, shows e shopping ou de ter acesso a viagens turísticas e bens culturais. Para esse grupo, restam parques e praças públicas, que em geral são escassos e deteriorados, terrenos baldios, ruas e praias, bem ainda, comércio e bares voltados ao público com pouco poder aquisitivo.

As expressões através da música, da dança, do corpo, do visual e de outras formas são os meios utilizados pelos jovens para articulações e troca de ideias. Há também, como será visto nas atividades desenvolvidas no CUCA, os jovens que se colocam na condição de produtores culturais, e não apenas na posição de usuários, agrupando-se para produzir músicas, artes, danças, peças teatrais, vídeos, fotografias.

Uma outra dimensão da condição juvenil é a sociabilidade, como explica Dayrell (2007, p. 1107) "a turma de amigos é uma referência na trajetória da juventude: é com quem fazem os programas, 'trocam ideias', buscam formas de se afirmar diante do mundo adulto, criando um 'eu' e um 'nós' distintivos". Pais (1993, p. 94), citado por Dayrell (2007), esclarece que os amigos do grupo "constituem o espelho de sua própria identidade, um meio através do qual fixam similitudes 
e diferenças em relação aos outros".

Há ainda os que apontam o lazer como um campo onde os jovens podem expressar suas aspirações e desejos, como forma de projetar um modo de vida, pois através das atividades de lazer e entretenimento ocupam parte considerável do seu tempo livre.

Brenner, Dayrell e Carrano (2008, p. 177) ressaltam a importância da cultura e do lazer como espaço produtor de sociabilidade da juventude, considerando como laboratórios, onde se processam diversas experiências juvenis:

\begin{abstract}
Nos espaços de lazer, os jovens podem encontrar as possibilidades de experimentação de sua individualidade e das múltiplas identidades necessárias ao convívio cidadão nas suas várias esferas de inserção social. As diferentes práticas de experiência coletiva em espaços sociais públicos de cultura e lazer podem ser consideradas como verdadeiros laboratórios onde se processam experiências e se produzem subjetividades.
\end{abstract}

O uso do espaço CUCA - Jangurussu, especialmente pelos jovens do Programa Comunidade em Pauta que praticam atividades artístico-culturais, apresenta-se como parte da dinâmica de sociabilidade juvenil, pois é um local que proporciona trocas de experiências, vivências e comportamentos da juventude, contribuindo para uma nova visão de mundo, bem ainda, fundamental na elaboração das identidades juvenis.

\title{
2. A política do Centro Urbano de Cultura, Arte, Ciência e Esporte
}

Os CUCAs são espaços que oferecem diferentes atividades gratuitas para as juventudes de Fortaleza, como cursos de formação, práticas esportivas, difusão cultural, protagonismo juvenil e promoção dos direitos humanos, priorizando jovens entre 15 a 29 anos. Os equipamentos também funcionam como locais de encontro e convivência da população jovem, possibilitando a sociabilidade e a participação juvenil, estimulando novas formas de integração e vivência dos seus valores e comportamentos.

Nas estruturas dos CUCAs é possível encontrar piscina semiolímpica, ginásio poliesportivo, salas de multimídias, pista de skate, anfiteatro, teatro, artes plásticas, laboratório de fotografia, sala de cinema, espaço para exposições artísticas, biblioteca. 
Para garantir a gestão do empreendimento social, foi criada uma Organização Social (OS), denominada Instituto Cuca, sendo uma associação civil de direito privado, sem fins lucrativos.

Segundo consta na documentação de criação do CUCA, a instituição situa-se como equipamento estratégico da política de juventude que busca consolidar um sistema integrado de programas direcionados a jovens, promovendo alternativas para o seu desenvolvimento econômico e sua inclusão social, contribuindo para reduzir as brechas de renda, desigualdades de oportunidades, econômicas e sociais da população do município. A proposta inicial era a construção de seis equipamentos padronizados e localizados em diversas partes da cidade, sendo cada um construído nas áreas das Regionais Administrativas da Prefeitura Municipal de Fortaleza. Todavia, até o momento, foram construídas três unidades nos bairros Barra do Ceará, Mondubim e Jangurussu, que fazem parte, respectivamente, da Secretaria Executiva Regional I, V e VI.

Especificamente quanto ao CUCA Jangurussu, foi inaugurado em janeiro de 2014, instalado no bairro Jangurussu, beneficia os 29 bairros da SER-VI, sendo esta a maior regional, ocupando uma área de $42 \%$ do território da capital cearense, com alta concentração de população jovem, apresenta o maior índice de analfabetismo, comparada com as demais regionais, assim como altos índices de criminalidades, principalmente no bairro onde está instalado o equipamento, considerado o mais violento da regional, conforme indicou o estudo do Mapa da Criminalidade e da Violência na cidade de Fortaleza - Perfil da SER VI'

Pensando nesse espaço como um local potencializador e que permite as vivências, os fazeres e agires da condição e diversidade juvenil, que foi analisado os jovens inseridos no Programa Comunidade em Pauta do CUCA Jangurussu, buscando compreender os modos de ser jovem nesse espaço e a questão da inclusão social dessa juventude.

\subsection{CUCA Jangurussu e as ações direcionadas aos jovens}

A pesquisa foi realizada a partir das entrevistas com jovens que praticam atividades artístico-culturais do programa Comunidade em Pauta e com os funcionários do CUCA Jangurussu, utilizando-se, para isso, roteiros semiestruturados, além dos registros no diário de campo, tais como descrição do local e conversas informais, as quais foram importantes para compreender a importância desse equipamento na vida de muitos os jovens que lá frequentam.

No total foram dez jovens entrevistado, de diversos grupos de dança, na faixa etária de 15 a 25 anos, os quais ocupam o espaço do CUCA para ensaiar, se reunir, passar o tempo, conhecer pessoas, fazer cursos, entre outras atividades. Outros jovens, que não participaram da entrevista propriamente dita, prestaram informações por meio de conversas informais, sendo registradas no diário de campo.

1 Cartografia da Criminalidade e da Violência na Cidade de Fortaleza - Perfil da SER VI - p. 144-154. Disponível em: < http://www.uece.br/labvida/dmdocuments/relatorio.pdf > Acesso em 26 jan 2017. 
Um equipamento como o CUCA, atrelado a uma política pública de juventude com proposta de diminuir as desigualdades e realizar inclusão social, atua em conjunto com ações de outras redes municipais, como a saúde, a assistência social e trabalho, prestando serviços à juventude e também à comunidade, como atendimento psicossocial e promoção à saúde, orientação profissional sobre mercado de trabalho, campanha de emissão de documentos de RG, CPF, Carteira de Trabalho, entre tantos serviços desenvolvidos de forma integrada com outras instituições sociais.

O CUCA disponibiliza ainda ações como serviços de visita guiada para escolas, instituições e grupos com até 50 pessoas, que desejam conhecer os espaços; atendimento de orientação à saúde e psicossocial; setor de economia criativa, responsável por direcionar os jovens quanto à orientação profissional, incluindo nesse departamento a Central de Ideias, que é voltada para atendimento e orientação aos interessados em desenvolver projetos e lançamento de editais; Coluna de Oportunidades, onde são expostas informações de emprego, estágios, oficinas, cursos, editais, prêmios e bolsas de estudo; Empregabilidade, no qual ensinam os jovens a criar seu currículo e ter noção de direito do trabalho; Empreendedorismo, com finalidade de estimular novos negócios, por meio do projeto Incubadora de Economia Criativa.

Analisando as ações desenvolvidas na unidade do Jangurussu, nota-se que este equipamento assume papel relevante na conscientização dos jovens como sujeitos de direitos. Através da promoção, em especial, da arte e da cultura, proporcionam uma visibilidade diferenciada a esses jovens, permitindo-os vivenciarem experiências que até então não faziam parte de seus cotidianos.

Em entrevista com um jovem, ex-usuário de drogas, foi perguntado sobre o significado do CUCA em sua vida, assim respondeu:

O CUCA é um aparelho muito bom para os jovens, mas possui muitas falhas, ainda não tem totalmente a nossa cara, aqui é muito burocrático. Muitas vezes, a gente precisa de caixa de som, microfone, e outras coisas e muitas vezes não têm, então não adianta só colocar um som para a galera ouvir e ocupar o espaço. Aqui falta uma metodologia de trabalho que consiga levar de fato as informações até às Comunidades e trazer os jovens para dentro do CUCA, principalmente a juventude que mora na periferia mais distante. Eu, por exemplo, tenho que pular a catraca do ônibus para vir para cá, não tenho dinheiro para pagar as passagens, mas preciso desse espaço do CUCA, sou ex-usuário de drogas, consumia cocaína, e o CUCA foi e ainda é muito importante para o meu tratamento de dependência química, a minha vida mudou completamente, aqui eu 
me encontrei no mundo, e hoje utilizo muito esse espaço, se isso aqui fechar será uma tragédia para mim e para muitos jovens daqui, eu amo o CUCA, apesar de algumas falhas, no geral a estrutura é muito boa, deveria ter muitos CUCAS espalhados nas periferias, para levar cultura, arte, lazer e esporte para a juventude carente que tanto precisa. (C.R, 24 anos, entrevistado em 05/04/2017).

Ao questionar sobre os maiores desafios para se gerir o equipamento, os funcionários entrevistados citaram questões como pouco recurso financeiro, falta de profissionais na área da cultura, não finalização da construção do teatro, necessidade de construção de mais CUCAs, entre outras, o que, às vezes, compromete o desenvolvimento das atividades e ações na unidade. Muitos jovens, por exemplo, desejam executar alguns projetos, porém se deparam com esses problemas, e isso, de certa forma, afasta alguns jovens que se sentem desestimulados de não terem sido contempladas suas expectativas, conforme narrou um funcionário:

[...] precisamos de mais profissionais nas áreas artístico-culturais, temos muitos jovens para atender com poucos espaços, por isso a importância da construção de mais CUCAS em outros bairros, para desafogar os CUCAS existentes. (entrevista realizada em 09/03/2017).

Pode-se dizer, que as ações desenvolvidas no CUCA somente terão efeitos se gerarem sentidos na vida dos jovens envolvidos, principalmente para aqueles que estão inseridos em locais de vulnerabilidades, que se sentem excluídos de acessos aos equipamentos públicos. Segundo explica Diógenes:

O desafio pode ser assim traduzido: ressignificar valores e atitudes dos adolescentes que se sentem excluídos e são realmente excluídos do acesso a equipamentos e serviços urbanos mais diversos, nos seus lugares de vida, nas suas práticas de espaço e, concomitantemente, interligá-los a toda rede de direitos que os constituam como sujeitos atuantes para além dos seus âmbitos costumeiros de atuação e vivência. Nossa empreitada é a de criarmos políticas para a juventude que, no geral, quando são distantes de suas aspirações, se apropriam ao seu próprio modo sem que se observe um envolvimento e uma mudança efetiva na condição de vida dos que usufruem dessas políticas. (DIÓGENES, 2009, p. 283) 
Para a efetivação de uma política pública de juventude, no aspecto do que é o CUCA, é preciso trabalhar com a pluralidade que rege as culturas juvenis, em especial, a dos jovens da periferia, os quais, em sua maioria, tiveram seus direitos violados, tendo o mínimo de acesso à arte, cultura, lazer, com poucas perspectivas de futuro, inseridos em ambientes de vulnerabilidade de risco, onde problemas com droga, criminalidade, violência são rotineiros, acabam considerando o equipamento como sua segunda casa, ou até mesmo um local de refúgio, como muitos dos jovens entrevistados afirmaram:

[...] moro no João Paulo II, lá tenho muitos amigos usuários de drogas, alguns já morreram por causa de dívidas de drogas, então, agradeço todos os dias pela existência do CUCA Jangurussu, passei a frequentar desde quando foi inaugurado, estou sempre aqui, quando não estou ensaiando com meu grupo, estou conversando com a galera, trocando ideia, venho para cá até no domingo, é melhor estar aqui do que em casa sem muita coisa para fazer [...] (T.V. S, 22 anos, entrevistada em 11/03/2017).

[...] estou aqui quase todos os dias, venho depois da aula, considero como minha segunda casa, é meu meio de refúgio, melhor estar aqui do que em casa fazendo besteira [...] ( V. L, 15 anos, entrevistado em 18/04/2017).

[...] o CUCA para mim foi a maior mudança que aconteceu na minha vida, na minha pré-adolescência eu era muito envolvido com drogas, minha mãe descobriu, ficava de castigo, apanhava, e quando o CUCA foi inaugurado, era o único local que minha mãe deixava eu frequentar, então no início eu só fazia esporte, depois fiz curso de desenho, em seguida entrei no grupo de teatro, aí foi a maior felicidade da minha vida. Hoje reduzi bastante o consumo de drogas, só fumo maconha, e o que me ajudou também foi que na Diretoria de Promoção de Direitos Humanos tem um trabalho de redução de danos. (I.O, entrevistado em 25/04/2017).

Sobre o significado do CUCA Jangurussu em sua vida, os jovens entrevistados deram respostas bem uniformes, como "oportunidade"; "é tudo, não sei o que seria da minha vida sem o CUCA"; " é a minha segunda casa”.

A partir dos relatos dos jovens, percebe-se a relevância de se manter uma política pública como a do CUCA, para isso há que se respeitar a diversidade cultural, social e sexual de modo a incluir todas as juventudes, conforme bem ressalta Diógenes: 
[...] as práticas culturais, artísticas e o campo do consumo não apenas devem ser considerados lugares relativos ao 'fazer política' como também pautados como esferas de produção dos elementos essenciais relativos à formação de uma agenda de realinhamento das políticas públicas de juventude. Desse modo, uma política para juventude deve levar em conta aspectos que recortam o conjunto de suas experiências, suas formas de sociabilidade e as marcas e os códigos de linguagem que balizam suas linhas de comunicação e produzem um reconhecimento entre seus pares. (DIOGENES, 2009, p. 278).

Mesmo com todas as dificuldades e barreiras, o CUCA vem se constituindo como um local pensado e construído para jovens, sustentando-se ao longo dos anos, possibilitando à juventude do Jangurussu e demais bairros usufruir da condição juvenil, oportunizando acessos que até então não possuíam.

\subsection{As práticas sociais dos jovens no espaço CUCA}

Para os jovens do programa Comunidade em Pauta, estar no CUCA, participar de suas atividades, ocupar seu espaço, configura-se como experiência social.

Apresentam-se, nesse cenário, três particularidades evidenciadas através das entrevistas e conversas informais, que configuram as relações entre os jovens e o CUCA, que são: muitos jovens se identificam com os educadores sociais e com a proposta da instituição; visibilidade das atividades praticadas pelos jovens e a dimensão educativa das ações desenvolvidas. Tais peculiaridades nada mais são que as experiências vividas pelos jovens no local, que representam formas de sociabilidade.

A questão da identificação dos jovens com o CUCA e com os educadores sociais é fruto das interações estabelecidas através dos processos de similitudes das trajetórias de vidas. Conforme constatado, os educadores são pessoas jovens e, a maioria, moradores da periferia, e, portanto, acabam vivenciando os mesmos problemas que se apresentam no local em que moram, compartilham elementos das culturas juvenis, como os gostos, estilos e identificações semelhantes, escutam as mesmas músicas, entre outros aspectos.

Portanto, ao participarem das atividades no CUCA, os jovens do Comunidade em Pauta têm contato direto com os educadores sociais, o que acaba representando, para alguns, uma possibilidade para as suas próprias trajetórias, constituindo uma alternativa de ser e viver, como ocorreu com alguns jovens que atualmente são educadores sociais e relataram que começaram a frequentar o CUCA, participaram de diversos cursos e quando abriu seleção para vagas de educadores inscreveram-se no processo seletivo, conseguiram aprovação, e atualmente estão trabalhando no equipamento. 
Quanto à visibilidade das atividades praticadas pelos jovens, foi observado que o CUCA contribui com as promoções de eventos culturais no equipamento, tais como peças de teatro, apresentações de dança, shows musicais, produções audiovisuais, as quais são divulgadas junto aos outros jovens e à comunidade em geral. Em alguns casos, ganha uma projeção maior, com a difusão nas redes sociais. Um exemplo dessa visibilidade promovida no equipamento foi a primeira Mostra Cultural, que aconteceu em janeiro de 2017, ocasião em que 17 grupos de dança se apresentaram no anfiteatro, inclusive recebendo um pequeno cachê, conforme afirmado pelo supervisor do Protagonismo Juvenil e, posteriormente, ratificado pelos jovens. A partir desse evento, alguns passaram a fazer apresentações em escolas, no Dragão do Mar e em outros locais.

Referente à dimensão educativa, observou-se que as ações desenvolvidas no equipamento procuram formas de (re)interpretação do espaço onde os jovens vivem. Por meio de campanhas e de rodas de conversa, discutem acerca da cidadania, da participação social, do protagonismo juvenil, da solidariedade, da diversidade e ainda estimulam a participação e a criatividade dos jovens. Estas práticas contribuem de alguma forma no processo de construção de saberes singulares.

Os jovens entrevistados demonstraram interesses quando foram discutidas questões relacionadas a grupos juvenis, às artes, culturas, danças e lazer, o que permitiram os estudos dos interesses e envolvimentos da juventude do CUCA com esses assuntos. Segundo esclarece Sposito (1996, p. 100-101):

Não ocorre, por acaso, o fato de que o mundo da produção cultural e das artes, em especial, a música, a poesia, o teatro e a dança, ocupam grande parte do universo de interesse juvenil. Os espaços hoje capazes de propiciar essas formas de agrupamento são raros e, neste campo, há um enorme vazio por parte do Estado em oferecer políticas públicas, especialmente destinadas aos setores jovens. Na maioria das vezes, as relações sociais mais significativas são gestadas fora da escola e da família, as tradicionais instituições socializadoras. O mundo do trabalho, quando é precocemente introduzido no universo do jovem pobre, nem sempre estrutura sua identidade de forma nítida. Ao que tudo indica, a sociabilidade tecida pela mediação dos vínculos com o mundo do trabalho tende a exercer menor força na conformação da identidade do jovem. Ao que parece o trabalho tornar-se mais fonte de renda, ou seja, um mero emprego, do que o exercício de um ofício que ofereça realizações pessoais. 
Isso pode ser evidenciado quando observados os jovens nas atividades da dança e da arte, pois, para eles, tem o sentido de lúdico, de externar o que sente, de liberdade de expressão, de poder trabalhar o corpo e a mente e, em muitos casos, sair da sua rotina:

Quase todos os dias estou aqui no CUCA, adoro estar aqui conversando com os amigos e ensaiando com meu grupo, escolhendo a música e os passos da coreografia. Através da dança você trabalha seu corpo e sua mente, faz bem para saúde, sai do sedentarismo, dá uma sensação de bem-estar. Quando estou dançando parece que meu corpo fala, quero alcançar a perfeição dos passos, fazer bonito mesmo para mostrar aos outros minha dança. Prefiro mil vezes estar aqui no CUCA fazendo alguma atividade do que em casa sem fazer nada, porque mente parada 'oficina do diabo', moro em periferia, onde há muitas drogas, tenho muitos amigos que usam e não quero essa vida para mim. Vivo dizendo para galera, vamos para o CUCA, lá tem muitas atividades, se você não gosta da dança, tem cinema, esporte, música ou então ficar só nas rodas de conversas com a galera, que é muito massa, trocar ideia com a galera, pelo menos sai um pouco daquele ambiente de drogas, aqui a gente esquece dos problemas e do mundo lá fora. (T.V. S, entrevistada em 11/03/2017).

Observa-se, ainda, que o companheirismo e a convivência estabelecida entre os grupos de amigos, além de desenvolverem suas atividades culturais, acabam criando laços de afeto, vínculos de confiança e também de pertencimento ao lugar, segundo dizem os próprios jovens "eu pertenço ao CUCA, como o CUCA me pertence, o CUCA só existe porque os jovens estão aqui”.

$O$ que se apresenta no momento são jovens inseridos no universo cultural plural e diversificado, que, por sua vez, necessita de novas formas de compreender as experiências de socialização, visto que há intensidade de produção e circulação de bens culturais, informações e acesso a diversas formas simbólicas com diferentes linguagens (DAYRELL, online, p.8-9). ${ }^{2}$

Assim, imersos em diferentes formas de sociabilidades, os jovens que transitam pelo CUCA constroem e compartilham diversos cenários e experiências, que os possibilitam difundi-los entre seus grupos.

A música, a dança, o corpo, o visual, entre outras formas têm sido utilizados como mediadores que agregam jovens para trocar ideias, dançar, ouvir um som ou apenas estar juntos sem compromissos. Entretanto, foi observado que no CUCA Jangurussu há também aqueles que se colocam como produtores culturais, que se juntam para produzir música, dança, vídeo, peça teatral, constatando-se a existência de diversidade de estilos.

2 DAYRELL, Juarez. Juventude, grupos culturais e sociabilidade. Disponível em: <file:///C:/Users/USER/Down- 
Através das atividades culturais desenvolvidas é que se estabelecem as relações de sociabilidade, os jovens entrevistados evidenciam esta sinalização, alguns afirmaram que a integração a um grupo cultural Ihes ajudou muito na convivência com o outro, a ser mais tolerante, a respeitar as diferenças, ouvir e entender o outro, interagir com grupos diversos, construir amizades, segundo relataram os jovens:

[...] aqui tem muitos jovens, de todos os estilos e de todas as tribos, a sociabilidade aqui no CUCA me ajudou muito a ter mais paciência, ser mais tolerante, a saber ouvir mais, porque você tem que saber ouvir, para entender o outro. (T.V. S entrevistada em 11/03/2017). [...] o Comunidade em Pauta me ajudou muito, pois a partir das reuniões mensais, pude conhecer os outros grupos, fazer amizades, até que conheci a galera do meu grupo e há quatro meses a gente se juntou para ensaiar performances de drag queen e através do Comunidade em Pauta vamos fazer nossa primeira apresentação esse mês (D.S, entrevistado em 18/04/2017).

Através das declarações dos jovens, percebe-se a importância do funcionamento de um equipamento como o CUCA num bairro de periferia, pois afirmaram que vivem em ambiente onde há muita violência, criminalidade, acesso fácil às drogas, que dependendo da escolha poderá ser fatal. esse contexto, os jovens reconhecem o valor das atividades culturais em suas vidas, como um dos meios de se afastarem das mazelas que os cercam, de conhecer outras pessoas, de ter oportunidade de vivenciar outras experiências, de preencher o tempo livre e de agregar algo positivo em sua vida.

\section{Comunidade em pauta: a dança como forma de ex- pressão cultural e inclusão social}

o CUCA, através do programa Comunidade em Pauta, cede os espaços físicos, de forma gratuita, para jovens desenvolverem suas habilidades artístico-culturais, dentre elas, destaca-se a dança.

Para ter acesso aos espaços é necessário ter idade entre 15 a 29 anos, fazer o cadastro na Diretoria de Promoção dos Direitos Humanos, participar das reuniões do Comunidade em Pauta, que ocorrem na última quarta-feira de cada mês, para assegurar os horários de 
utilização das salas multiuso e da sala de artes cênicas, além de atender os regulamentos estabelecidos no programa. De acordo com as informações prestadas pelo supervisor de Protagonismo Juvenil, atualmente são atendidos em média 40 grupos por mês, de diversas modalidades de dança, que acessam os ambientes conforme os horários pré-agendados. Todavia, ressaltou que quando os jovens não conseguem referidos espaços, podem livremente usar os locais abertos do equipamento para ensaiar.

O CUCA, por meio do referido programa, propõe-se a fornecer subsídios teóricos e práticos para potencializar as ações culturais, que a maioria dos jovens já desenvolvia e, ao mesmo tempo, estimulá-los a assumir o papel de agentes culturais, assim como, contribui para criar e/ou ampliar os espaços de encontro e de formação na comunidade onde atuam. Isso se evidencia pelos relatos colhidos, dentre esses a de uma jovem que utiliza os espaços do CUCA Jangurussu desde sua inauguração:

\footnotetext{
[...] eu já dançava com minhas amigas muito antes da existência desse CUCA, a gente ensaiava na minha casa, na época o grupo era só de quatro meninas, com a inauguração do CUCA Jangurussu, a gente passou a ensaiar aqui toda semana, temos mais privacidade, as salas são ótimas, principalmente a sala de artes cênicas que tem espelhos, mais amigas aderiram ao grupo, atualmente somos nove, a gente já se apresentou em algumas escolas do bairro e aniversários de amigos, dançando as coreografias da Beyonce, e também aqui no CUCA a gente aprendeu a fazer vídeos e colocar no YouTube, temos alguns vídeos postados, com muitas visualizações (L.R, conversa registrada no diário de campo em 14/02/2017).
}

Segundo Dayrell (online, p.13) "a cultura juvenil tende a transformar os espaços físicos em espaços sociais, pela produção de estruturas particulares de significados". Como lembra Pais (1993, p. 96), citado por Dayrell (online, p. 13), "as culturas juvenis, para além de serem socialmente construídas, têm também uma configuração espacial”.

Por estar inserido no cotidiano da periferia, propondo atividades diversificadas no campo da cultura, o CUCA acaba sendo um lugar de referência para muitos jovens, conforme se vê nos trechos a seguir:

[...] com o CUCA eu consegui ter uma projeção artística, porque desde sempre quis me envolver com artes, fazer teatro, desde de criança mesmo, e não sabia como começar, onde procurar, então através do CUCA, conseguiu me mostrar

3 DAYRELL, Juarez. Juventude, grupos culturais e sociabilidade. Disponível em: <file:///C:/Users/USER/Downloads/grupos+juventude\%20(2).pdf>. Acesso em: 22 mar. 2017. 
que era possível ter acesso a arte e a diversas culturas, foi a partir do CUCA que eu entrei no grupo de teatro, sou integrante do grupo Cia. Breu de Vagalumes, a gente já fez diversas apresentações, tanto aqui como nos outros CUCAS, e também integro o grupo de dança de performance de drag queen (M.S entrevistado em 25/04/2017).

Evidencia-se que a presença de um instrumento como o CUCA modifica, de certa forma, positivamente a vida de muitos jovens. Com acessos gratuitos e diversidade de atividades, reunindo em seu espaço jovens de vários estilos, gostos, afinidades, sonhos e histórias, como constatado nas narrativas a seguir:

[...] quando entrei no curso de teatro aqui no CUCA, mudou tudo em minha vida, pois o CUCA mostrou outras vertentes artísticas que eu não conhecia, já fiz passeios nos outros CUCAs para assistir peças teatrais, o CUCA já me proporcionou passeios no Dragão do Mar e no BNB para assistir apresentações artísticas, de teatro, dança, música, e para mim isso foi muito bom, pude ter acesso a essas coisas, que antes eu não tinha, principalmente por não ter condições financeiras, então, o CUCA proporciona para mim, tanto a parte de lazer, como também ajuda na construção do meu lado artístico. (D. R, entrevistado em 25/04/2017)

[...] passei a frequentar o CUCA através de um amigo que dança num grupo de Break, comecei a aprender alguns passos, fiz aqui no CUCA alguns cursos de dança de rua, com o professor Charada, o cara é muito bom, aprendi algumas técnicas, comecei a treinar com uns amigos e formamos um grupo, a galera aqui arrebenta, são feras, tem que ter muito treino e determinação, meu tempo livre é para treinar os passos, gosto de humilhar a galera (risos) (C.A, entrevistado lem 18/04/2017).

Para os jovens entrevistados, a dança é considerada como um agente transformador, que potencializa a descoberta do mundo e de si mesmo, com cargas de desejos e desafios. A dança trabalha diversas partes do corpo, externa sentimentos de satisfação e alegria, atribui significados à vida, já que instiga a imaginação e a criatividade. Além disso, verificou-se que os jovens do Comunidade em Pauta visualizam na dança uma projeção profissional.

Durante as visitas no CUCA Jangurussu, foram presenciados ensaios e apresentações dos grupos de dança, de várias modalidades, hip hop, swing, axé, break, pop, forró, entre outras, destacando-se os eventos, como o da primeira Mostra Cultural, que ocorreu em 
janeiro/2017, quando 17 grupos do Comunidade em Pauta se apresentaram no Anfiteatro, e da Apresentação Cultural de Dança, em abril/2017, ocasião em que se apresentaram 10 grupos. Em ambos, constatou-se o empenho, dedicação, senso de responsabilidade e profissionalismo dos jovens, um verdadeiro espetáculo, desde a sincronia dos movimentos até a liberdade dos passos, cada grupo com seu estilo, demonstrando que os jovens estão usando o espaço não apenas para diversão, brincadeira ou passatempo, e sim, levam a sério o trabalho desenvolvido pelo seu grupo de dança.

Acerca das atividades que os jovens gostariam de fazer, e que ainda não foram oferecidas pelo CUCA e as sugestões de melhorias do equipamento, obteve-se respostas bem similares, tais como aquisição de mais caixas de som, construção de outras salas de multiuso, contratação de bons profissionais na área cultural, cursos de dança com longa duração, conforme os relatos a seguir:

[...] o CUCA abriu um leque de oportunidade para mim, e para muitos jovens, porque quem não tem um empresário, o CUCA ajuda muito, é uma "mão na roda". Mas também tem algumas falhas, por exemplo, a questão do ar-condicionado na sala de artes cênicas, se tivesse mais caixas de som, cabos, questões técnicas mesmo, pois a galera não tem acesso, não tem condições econômicas para comprar, aqui têm 3 salas de multiusos, e duas caixas de som, sempre fica uma sala sem som. Se tivesse mais salas de multiuso seria muito bom e também se tivesse aulas de balé, para melhorar na postura corporal e nas técnicas de dança, seria maravilhoso (T.V. S, entrevistada em 11/03/2017).

[...] queria que tivesse aulas de dança de rua com mais frequência, esse ano contrataram o professor Charada, mas as matrículas logo terminaram, estou esperando nova turma. A questão de mais salas com caixa de som para gente ensaiar seria bom, porque aqui tem muitos grupos, se a gente faltar às reuniões do Comunidade em Pauta a gente perde o horário da sala, aí a gente ensaia nos espaços aberto. (J. K, entrevistado em 18/04/2017).

[...] gostaria muito que o CUCA fizesse parcerias com outros polos culturais, pois aqui no CUCA você não sai completamente formado, aqui te dar o caminho, tanto é, que os cursos oferecidos têm duração de no máximo três meses ou pequenas oficinas, que são realizadas para despertar o interesse, diferente, por exemplo, na Vila das Artes que oferece cursos de duração de 6 meses a um ano de dança, para os jovens que desejam fazer balé, por exemplo, se deslocarem para o centro da cidade, é bem complicado por questões financeiras, seria muito interessante se o CUCA fizesse parcerias e tivesse um trabalho de proporcionar a mobilidade daqui para o Vila das Artes, ou então para outros 
polos culturais de formação, esse é o meu desejo. (I.O, entrevistado em 25/04/2017).

Pelos relatos, verifica-se queos jovens reconhecem a importância do CUCA Jangurussu como um local que oportuniza projeções profissionais, construções de sonhos, acessos culturais, mas, ao mesmo tempo, perceberem que, como política pública de juventude, poderia proporcionar mais instrumentos para os jovens da periferia, especialmente para aqueles que desejam seguir no caminho artístico-cultural. O CUCA, para muito jovens, representa alternativa de mudança da vida, ampliação dos horizontes, perspectivas e vivências, até então inimagináveis.

Para a maioria dos jovens entrevistados, o cotidiano vivenciado no CUCA permite que eles se conheçam melhor, enxergando suas limitações e suas potencialidades, além de vislumbrarem, nas atividades que praticam, uma perspectiva de seguirem uma trajetória profissional, mesmo reconhecendo as dificuldades de sobreviverem financeiramente por meio da arte, conforme alguns relatos sobre as expectativas futuras nessa área:

[...] quero me formar em teatro e depois especialização em dança, ou teatro, ou música, sei que é difícil, mas pretendo viver só da arte, com produção artística, pesquisa na arte (I.O, entrevistado em 25/04/2017).

[...] quero fazer curso de teatro na UFC ou IFCE (Instituto Federal de Educação, Ciência e Tecnologia do Ceará), pretendo investir mais na minha carreira de drag queen, ganhando dinheiro, desejo também gravar algumas músicas que escrevi, já fiz aulas de canto aqui no CUCA, pretendo me especializar mais em música e trabalhar a minha voz, (D. $R$, entrevistado em 25/04/2017)

Quanto à participação dos jovens no equipamento, contatou-se que são bem atuantes, na medida em que, junto com seus coletivos, confirmam sua condição juvenil, seus estilos, suas escolhas e suas ações. Todavia, ainda que não tenha sido possível identificar, de forma clara, as formas de participação dos jovens no processo de tomada de decisão no equipamento, constatou-se que os coletivos juvenis se organizam para reivindicar suas demandas, como, por exemplo, acesso aos horários dos seus ensaios, eventos para seus grupos apresentarem-se no espaço e cursos para se aprimorarem, sendo essas solicitações em parte atendidas. 


\section{Considerações finais}

Esta pesquisa procurou investigar de que maneira as atividades artístico-culturais desenvolvidas no CUCA Jangurussu contribuem no processo de inclusão social dos jovens da periferia.

Após conhecer um pouco do universo CUCA e percorrer seus espaços, despertou a atenção para pesquisar os jovens envolvidos em atividades artístico-culturais do Programa Comunidade em Pauta. Constatou-se que esses jovens são da faixa etária de 15 a 25 anos, em sua maioria estudantes, moradores do bairro Jangurussu e bairros próximos do equipamento, estão ligados a grupos de artes e culturas, principalmente na área da dança, sendo de diversas modalidades, a maioria frequenta o equipamento desde sua inauguração.

As palavras dos jovens sobre seus cotidianos no CUCA Jangurussu, informando seus pontos de vistas acerca das vivências neste espaço e inseridos em um contexto social com restrições e cerceamentos, possibilitaram conhecer as experiências criativas na forma de viverem sua condição juvenil.

Constatou-se que o fato de morarem em área de periferia, com problemas de criminalidade, violência, drogas, ausência de equipamentos públicos para garantir, em parte, seus direitos como cidadãos, acabam dificultando viverem sua condição juvenil por completo.

Todavia, os jovens acenaram para a importância do funcionamento do CUCA em bairro da periferia, assim como o desejo de continuidade do funcionamento desse equipamento, haja vista que é um lugar onde passam boa parte do seu tempo, inclusive considerando como sua segunda casa, preferindo estar nesse local ao invés das ruas ou outro lugar. Além disso, consideram-no como um espaço público de sociabilidade, onde desenvolvem estratégias que permitem empreender atividades do cotidiano, como formar amigos, trocar experiências, aprender algo novo, divertir-se, ou seja, desenvolver práticas que caracterizam seus modos de vida.

Um aspecto bem evidenciado foi a questão do pertencimento ao equipamento, através das declarações prestadas pelos próprios jovens, percebeu-se que eles se reconhecem como sujeitos de direitos e ocupam o espaço porque foi construído para eles, ao afirmarem: "o CUCA foi construído para nós"; "quem faz o CUCA é o jovem"; "eu pertenço ao CUCA, como o CUCA me pertence"; "se os jovens deixarem de vir para o CUCA, ele deixa de existir"; "considero o CUCA como minha segunda casa".

Observou-se que, para esses jovens, o CUCA é um espaço de referência, que propõe vivências e conhecimentos diferenciados, por oferecer atividades e ações que dificilmente teriam acesso devido ao contexto social em que estão inseridos, como por exemplo, teatro, dança, cinema, música e esporte. Assim, acabam criando identificação com o local e também laços de amizade com os educadores sociais, assumindo os discursos e propostas da instituição.

Evidenciou-se ainda que os jovens ressentem-se de um olhar mais atento para suas deman- 
das, haja vista que o equipamento poderia fornecer mais atividades e cursos na área cultural, em especial na dança, bem como uma melhor projeção profissional, pois os cursos e oficinas voltados para essa área são de curta duração, apenas para despertar o interesse; para quem deseja se aperfeiçoar e aprender novas técnicas corporais, tem que procurar outros meios, o que muitas vezes, torna-se bem difícil, sobretudo, quando envolvem recursos financeiros.

Todavia, para os jovens entrevistados o CUCA Jangurussu é, no geral, um espaço de possibilidades para construírem seus projetos, desejos e de se firmarem como sujeitos que possuem direitos. A aproximação com os jovens, durante as visitas de campo, demonstrou que são sujeitos cheios de alegrias e disposições para construir um futuro diferente, vendo naquele espaço oportunidade de desenvolverem suas habilidades e depositando esperança de seguirem um caminho profissional. 


\section{Referências}

BRASIL. Lei no 12.852, de 5 de agosto de 2013. Institui o Estatuto da Juventude e dispõe sobre os direitos dos jovens, os princípios e diretrizes das políticas públicas de juventude e o Sistema Nacional de Juventude - SINAJUVE. Diário Oficial da União, Brasília, DF, 06 ago. 2003.

BRASIL, Glaucíria Mota et al. Cartografia da Criminalidade e da Violência na cidade de Fortaleza. Fortaleza: FUNECE, 2010. Disponível em: <http://www.uece.br/labvida/dmdocuments/relatorio. pdf >Acesso em: 26 jan. 2017.

BRENNER, Ana Karina; DAYRELL, Juarez; CARRANO, Paulo. Cultura do lazer e do tempo livre dos jovens brasileiros. In. ABRAMO, Helena Wendel e BRANCO, Pedro Paulo Martoni (org.). Retratos da Juventude brasileira. São Paulo: Editora Fundação Perseu Abramo, 2008. p. 175-214.

CARRANO, Paulo. Juventudes e Cidades Educadoras. Petrópolis: Vozes, 2003.

CATANI Afrânio Mendes; GILIOLI, Renato de Sousa Porto. Culturas juvenis: Múltiplos olhares. São Paulo: Unesp, 2008.

DAYRELL, Juarez. A escola faz as juventudes? Reflexões em torno da socialização juvenil. Educação e Sociedade. Campinas, vol. 28, no 100 - Especial, p. 1105-1128, out. 2007. Disponível em: <http:// www.cedes.unicamp.br>. Acesso em 15 jan. 2017.

Juventude, grupos culturais e sociabilidade. Disponível em: < file:///C:/Users/USER/ Downloads/grupos+juventude\%20(2).pdf> Acesso em: 22 mar 2017.

DIÓGENES, Glória. Juventude, exclusão e a construção de políticas públicas: estratégicas e táticas. In: MENDONÇA FILHO, Manoel; NOBRE, Maria Teresa (Org.). Política e afetividade: narrativas e trajetórias de pesquisa. Salvador: EDUFBA/ EDUFS, 2009, p. 271-288. 
ESTATUTO CONSOLIDADO DO INSTITUTO DE CULTURA, ARTE, CIÊNCIA E ESPORTE. Instituto Cuca. Fortaleza, 2014.

IBGE. Instituto Brasileiro de Geografia e Estatística. Censo Demográfico. Brasília, 2010.

PAIS, José, Machado. A construção sociológica da juventude: alguns contributos. Análise Social, vol. XXV (105-106), 1990 (1. $\left.{ }^{\circ}, 2^{\circ}{ }^{\circ}\right), 139-165$. Disponível em <http://analisesocial.ics. ul.pt/documentos/1223033657F3sBS8rp1Yj72MI3.pdf>. Acesso: 20 set. de 2016.

- Jovens e Cidadania. Sociologia, Problemas e Práticas. n. - 49, 2005, pp. 53-70. Disponível em: <https://repositorio-Iul.iscte.pt/bitstream/10071/202/1/SOCIOLOGIA49_cap03.pdf> Acesso em: 06 fev. 2017.

SECRETARIA NACIONAL DE JUVENTUDE. Disponível em: < http://juventude.gov.br/> Acesso em: 15 dez. 2016.

SPOSITO, Marília Pontes; CARRANO, Paulo César Rodrigues. Juventude e políticas públicas no Brasil. Revista Brasileira de Educação, Rio de Janeiro, n. 24, p. 16-39, set./dez. 2003. 